ROCZNIKI PEDAGOGICZNE

Tom 11(47), numer specjalny -2019

DOI: http://dx.doi.org/10.18290/rped.2019.11s-26

SŁAWOMIR STASIOROWSKI

\title{
PODSTAWOWE CZYNNIKI WPŁYWAJĄCE \\ NA FUNKCJONOWANIE SYSTEMU READAPTACJI SPOŁECZNEJ SKAZANYCH - DIAGNOZA I ROZWÓJ
}

Skuteczność społecznej readaptacji skazanych jest uwarunkowana przyjęciem założenia o jej nierozerwalności z innymi współtowarzyszącymi procesami, między innymi resocjalizacją oraz pracą socjalną, a także zależności od prowadzonej polityki kryminalnej Państwa. Świadomość wielowymiarowych potrzeb jednostki, która niejednokrotnie wymaga wsparcia w przezwyciężeniu problemów, uznawanych przez ogół społeczeństwa za „zwyczajne”, stanowi zazwyczaj początek jej reintegracji ze społeczeństwem.

Obserwując współczesne funkcjonowanie podmiotów działających w obszarze readaptacji społecznej skazanych (por. Pierzchała, 2015; 2016) nie można oprzeć się wrażeniu, iż działają reaktywnie - w zakresie stwierdzonych problemów i potrzeb skazanych oraz w sposób odrębny, a niekiedy konfrontacyjny wobec siebie, powielając swoje działania, zadania i aktywności. Proces włączenia społecznego, w szczególności osób powracających do społeczeństwa po odbyciu długoterminowej kary pozbawienia wolności, nie odbywa się zatem w ramach jednego programu, lecz w ramach wielu programów i działań doraźnych, które z rzadka uwzględniają się wzajemnie, uznając jako priorytetowe cele uznawane za najbardziej istotne z punktu widzenia konkretnej instytucji lub podmiotu. Tymczasem nie jest możliwe realizowanie wielu celów głównych i wielu celów szczegółowych w tym samym odcinku czasowym. Nie jest również możliwe ułożenie prawidłowej relacji między skazanym a przedstawicielami instytucji, np. pomocy społecznej, rynku pracy i kuratorem

Dr SŁaWomir Stasiorowski - prawnik, kurator specjalista, wykładowca Wydziału Pedagogiki i Psychologii Uniwersytetu w Białymstoku oraz Krajowej Szkoły Sądownictwa i Prokuratury; e-mail: slawomir.stasiorowski@gmail.com 
sądowym, z których każdy oczekuje i wymaga innego zakresu zaangażowania ze strony podmiotu postępowania wykonawczego. Proces, o którym mowa, winien odbywać się w ramach jednego ujednoliconego programu i być prowadzony przez jeden wiodący podmiot koordynujący. W ramach wolności kontrolowanej, a więc w okresie wykonywania kary wolnościowej lub warunkowego zwolnienia z odbycia reszty kary pozbawienia wolności, naturalnym koordynatorem i organizatorem włączenia skazanego do życia społecznego jest kurator sądowy, którego rola powinna zostać wzmocniona i podkreślona systemowo.

\section{POLITYKA KRYMINALNA}

Określana jest jako system różnorodnych i powiązanych ze sobą środków państwowych i społecznych skierowanych na zapobieganie przestępczości, usuwanie przyczyn i sprzyjających jej okoliczności oraz maksymalne - w danych warunkach - ograniczanie możliwości występowania wszelkiego rodzaju czynników kryminogennych (Jaroch, 2012, s. 49). Przyjmuje się, że na politykę kryminalną składają się:

1) polityka karna - działania polegające na stosowaniu systemu środków karnych i pozakarnych oraz ich skuteczność; polityka karna obejmuje działania organów ścigania, stosowanie środków zapobiegawczych, politykę sądowego wymiaru kary (indywidualizacja wymiaru kary), analizę ustalonych w trakcie postępowania czynników sprzyjających przestępczości i stanowiących nadal realne zagrożenie (Krukowski, 1982);

2) działalność legislacyjna - tworzenie norm prawa eliminujące zagrożenia kryminogenne, obejmujących prawo materialne, procesowe oraz związane z wykonaniem sankcji karnych;

3) polityka wykonawcza - obejmująca postępowanie w zakresie wykonania sankcji karnych, w tym postępowanie wychowawczo-resocjalizacyjne, profilaktyczne i kontrolne, lecznicze - w szczególności terapeutyczne, korekcyjno-edukacyjne i szeroko rozumianą rehabilitację sprawcy przestępstwa oraz zabezpieczenie społeczeństwa przed nim - izolacja więzienna oraz dolegliwości towarzyszące karze.

Z kolei B. Hołyst (2016) polityką kryminalną określa całokształt zagadnień dotyczących zapobiegania przestępczości, a obok polityki karnej wymienia również:

1) profilaktykę kryminalistyczną - czyli zespół metod i środków mających na celu uniemożliwienie albo utrudnienie przestępstwa, wśród których dominują 
elementy obiektywne, sprowadzające się przede wszystkim do fizycznego przeciwdziałania zamiarowi realizacji akcji przestępczej;

2) profilaktykę kryminologiczną - obejmującą przede wszystkim zagadnienia genezy i etiologii czynu przestępnego i operując głównie metodami z zakresu psychologii i pedagogiki społecznej, która ma na celu nadanie pozytywnego kierunku aktywności ludzkiej oraz wywarcie wpływu na zmianę negatywnych postaw i tendencji;

3) profilaktykę penitencjarną - sprowadzającą się do wykonania kary, która ma na celu wyłącznie takie ukształtowanie warunków jej przebiegu, aby w optymalnym stopniu realizować funkcje resocjalizacji.

Wydaje się, że z punktu widzenia możliwości realizowania zadań polityki kryminalnej w zakresie stosowania środków profilaktycznych, w szczególności przeciwdziałania przestępczości powrotnej, znacząco większe możliwości oddziaływania aniżeli Służba Więzienna - zarówno w wymiarze społecznym, jak $\mathrm{i}$ indywidualnym - ma kuratorska służba sądowa. Kuratorzy sądowi na koniec 2017 roku prowadzili stałe oddziaływania wobec około 560 tys. osób, gdy Służba Więzienna - wobec około 75 tys. osadzonych. Co istotne, kurator sądowy oddziałuje w środowisku otwartym nie tylko wobec podmiotu postępowania wykonawczego i jego środowiska rodzinnego, ale ma możliwość animowania środowiskiem lokalnym, stosując zarówno metody pracy resocjalizacyjnej poprzez wpływ środowiska na rodzinę, jak i na konkretnego skazanego. Może również prowadzić projektowaną działalność profilaktyczną na wszystkich poziomach profilaktyki, zatem uniwersalnym, selektywnym i wskazującym, przy zastosowaniu niemal wszystkich strategii profilaktycznych.

Jedną z podstawowych zasad skutecznej profilaktyki jest możliwość konfrontowania człowieka z niebezpieczeństwem (pokusą zachowania ryzykownego) oraz możliwość uruchamiania takich działań, które wprowadzą pożądane zmiany w funkcjonowaniu człowieka pozostającego w zagrożeniu. Taką możliwość daje niemal wyłącznie środowisko otwarte. Faktyczne oddziaływania profilaktyczne prowadzone wobec osadzonych mają raczej charakter działań prewencyjnych, które zabezpieczają społeczeństwo przed skazanym potencjalnie niebezpiecznym, z drugiej strony zaś zabezpieczają jednostkę przed możliwością powrotu do przestępstwa. Skazany konfrontowany jest z „pokusą” zachowania ryzykownego wyłącznie w warunkach świadomości permanentnej kontroli podczas czasowego uwolnienia, tj. pracy w systemie bez konwojenta poza zakładem karnym, po uzyskaniu zgody na czasowe opuszczenie jednostki penitencjarnej, przerwy w karze czy warunkowego zwolnienia.

Niezależnie od zakresu zarysowanych granic polityki kryminalnej, należy zauważyć, że wyznaczone przez nią kierunki determinujące pozostałe sfery 
działalności państwa, urzeczywistnia działalność legislacyjna, przez którą formuje się polityka karna.

Z punktu widzenia rozwoju systemu readaptacji społecznej decydujące znaczenie ma sposób reakcji karnej na popełnienie przestępstwa. Polska polityka karna ma charakter silnie prizonizujący. Do 2015 roku była oparta na karze pozbawienia wolności, której wykonanie warunkowo zawieszano. Jeszcze w 2015 roku jej odsetek w ogólnej liczbie kar przekraczał 50\%. Ustawą z dnia 20 lutego 2015 roku o zmianie ustawy - Kodeks karny oraz niektórych innych ustaw (Dz. U. 2015 roku, poz. 396) pozornie odwrócono ten stan rzeczy. Od tego czasu polskie sądy orzekają wprawdzie w większości kary wolnościowe, lecz jednocześnie znacząco podniósł się udział kary bezwzględnej pozbawienia wolności, przynosząc efekt podwyższonej liczby osób przebywających w izolacji więziennej. Opisane tendencje ukazuje wykres 1.

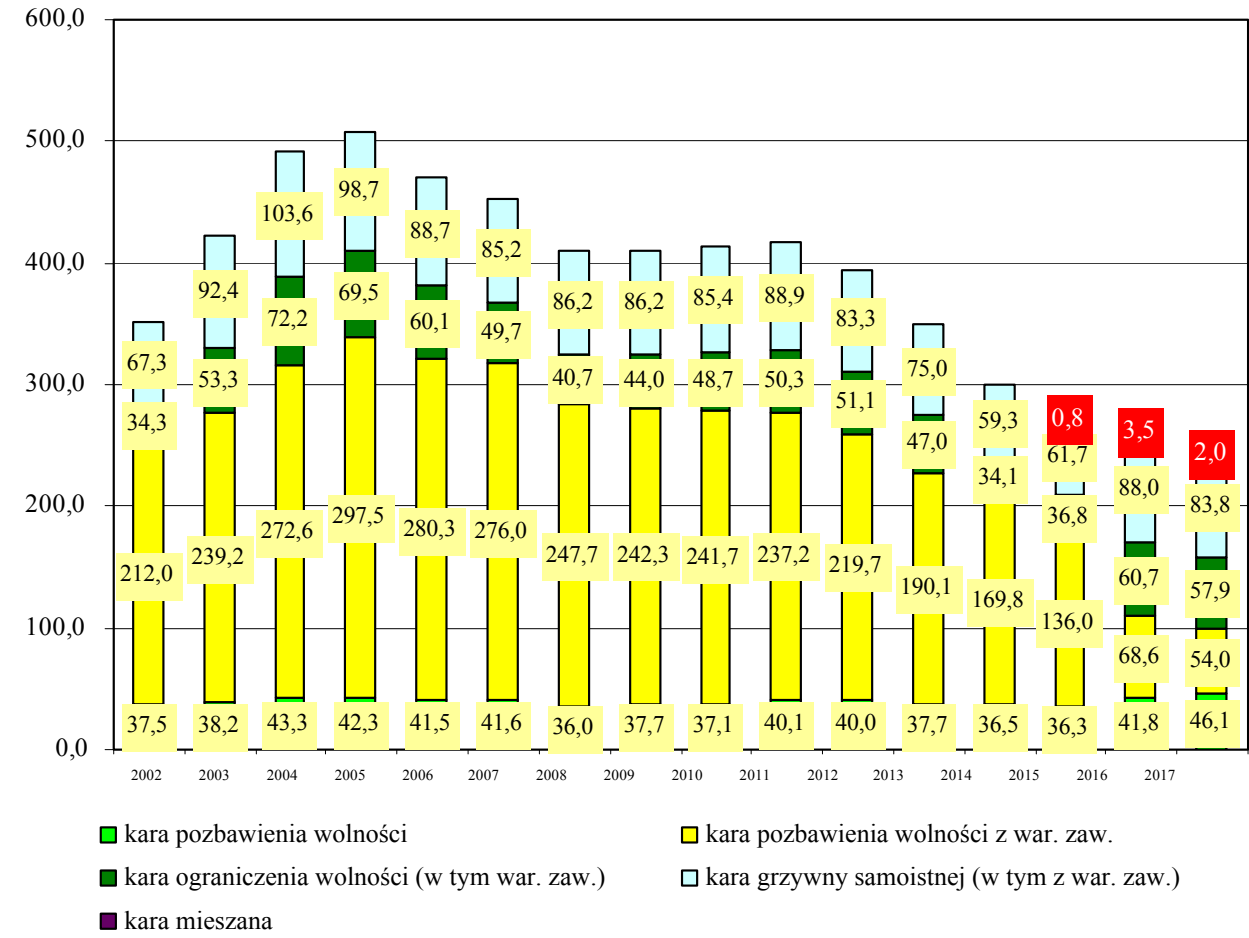

Wykres 1. Osoby skazane przez sąd pierwszej instancji w latach 2002-2017 w sądach rejonowych.

Opracowanie własne (Sprawozdanie MS-S6r). 


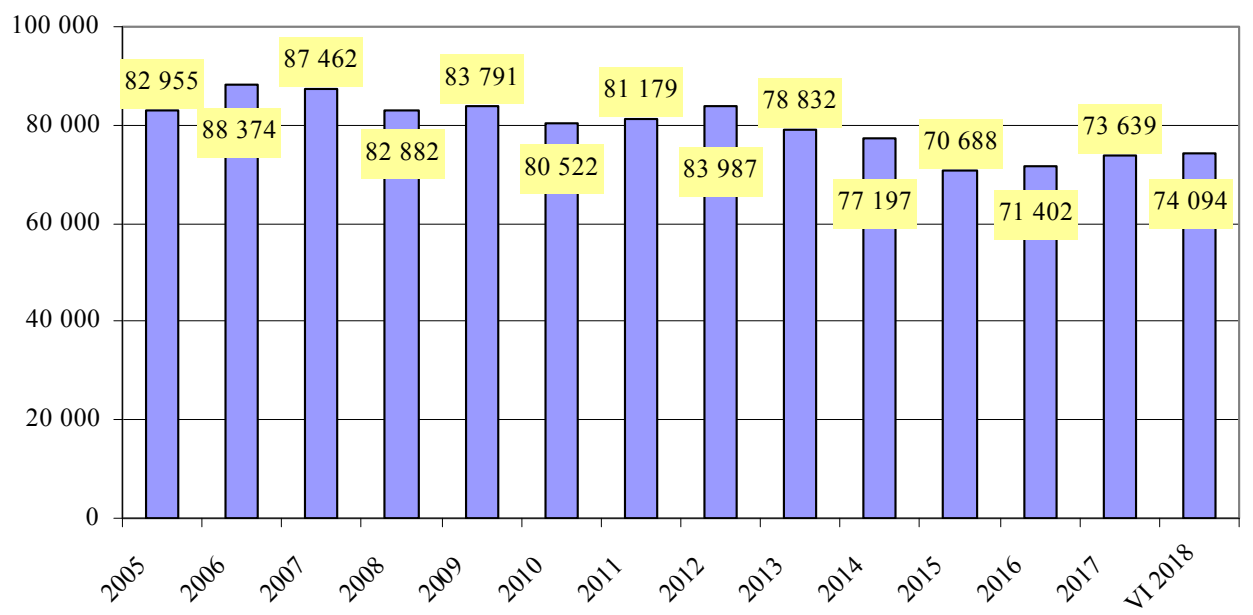

Wykres 2. Zaludnienie faktyczne zakładów karnych i aresztów śledczych na ostatni dzień okresu statystycznego w latach 2005-2018. Opracowanie własne.

Źródło danych: https://www.sw.gov.pl/strona/statystyka-roczna [dostęp: 2018.07.24].

Pomimo zadowalającego spadku liczby popełnianych przestępstw, w Polsce wskaźnik inkarceracji, który odzwierciedla liczbę osób pozbawionych wolności, był i pozostaje na wysokim poziomie, tj. około 200 osób na 100 tys. mieszkańców.

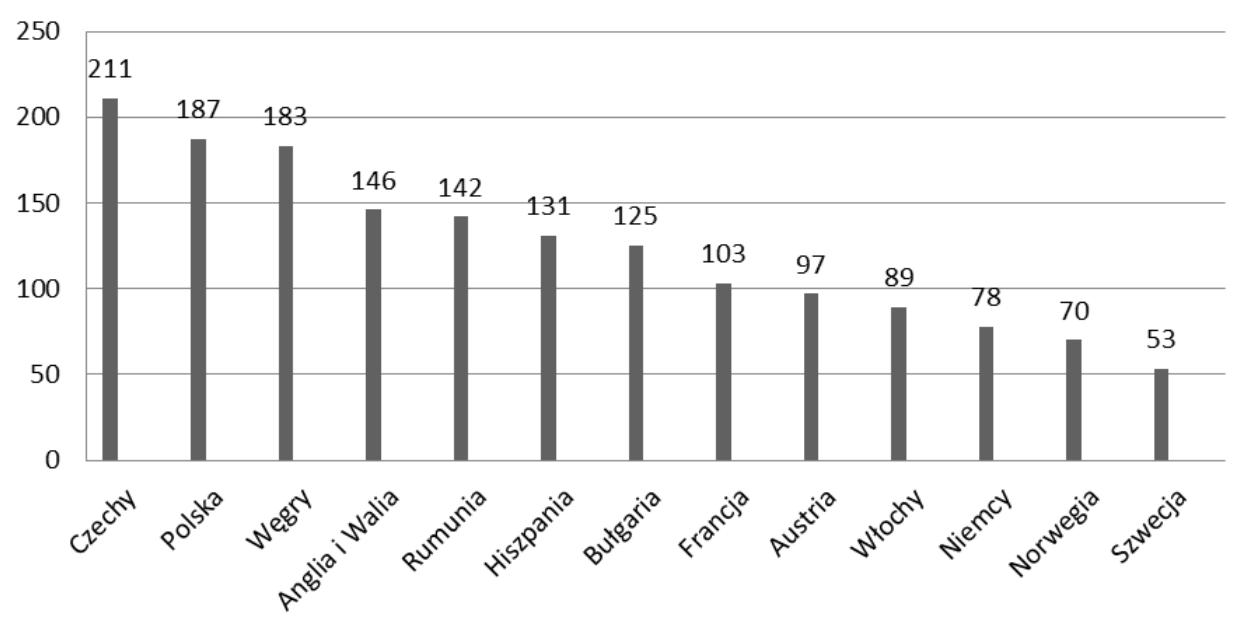

Wykres 3. Wskaźnik inkarceracji w wybranych krajach - wrzesień 2016 r. Opracowanie własne. Źródło: International Centre form Prison Studies. 
Liczba osadzonych ponownie zaczęła wzrastać w 2016 r. Na dzień 31 stycznia 2017 r. było ich w Polsce już 72677 (na dzień 30 kwietnia 2018 r. liczba osadzonych w zakładach karnych i aresztach śledczych wynosiła 75101 , w tym: tymczasowo aresztowani 7432, skazani 66669 i ukarani 1000; źródło: http://www.sw.gov.pl/strona/statystyka--miesieczna). Biorąc pod uwagę liczbę mieszkańców (wg Eurostatu 37,93 mln mieszkańców) oznacza to, że wskaźnik prizonizacji ponownie wzrósł do 192 osób na 100 tys. mieszkańców (Źródło: http://www.prisonstudies.org/country/poland [dostęp: 2018.06.18].

Wzrost liczby osób przebywających w izolacji więziennej oznacza potencjalnie większe koszty utrzymania więziennictwa, więcej osób zwalnianych z jednostek penitencjarnych, wyższą liczbę klientów kuratorskiej służby sądowej, pomocy społecznej i innych instytucji pomocowych. W 2017 r. skreślono z ewidencji jednostek penitencjarnych łącznie 78761 osób, w tym 48650 skazanych, 20054 ukaranych oraz 9723 tymczasowo aresztowanych.

Cel wychowawczy kary należy odczytywać w szerokim kontekście - jako proces indywidualnego, świadomego wpływu na ludzkie zachowania i postawy ze strony opiekuna (pedagoga), który jest ściśle związany z potrzebą zapobiegania powrotowi do przestępstwa. Możemy go osiągnąć poprzez reorientację postaw sprawcy przestępstwa, nastawień, przekonań i zachowań (resocjalizacja) oraz przystosowanie go na nowo do życia w społeczeństwie na jego zasadach (readaptacja). W centrum zainteresowania powinien znajdować się człowiek, któremu system winien zaproponować na tyle atrakcyjną alternatywę kontynuowania egzystencji, by ten nabrał przekonania o potrzebie przestrzegania norm i wartości społecznych. Komentatorzy życia społecznego zapominają bowiem, że każdy zakres oddziaływania na jednostkę, w tym także resocjalizacyjnego, jest co do zasady wyłącznie ofertą, którą skazany może przyjąć lub odrzucić.

Prawo karne dysponuje szerokim wachlarzem możliwości oddziaływania na sprawcę przestępstwa, tj. poprzez zróżnicowany katalog kar, środków karnych (które wymierzane są obok kary, stanowiąc dodatkową dolegliwość dla sprawcy), przepadek i środki kompensacyjne (podobnie jak środki karne wzmacniają dolegliwość reakcji karnej poprzez uczynienie przestępstwa nieopłacalnym: obejmują utratę zarówno przedmiotów pochodzących z przestępstwa, jak i utratę korzyści majątkowej uzyskanej z przestępstwa, a także rodzą skutki finansowe wobec pokrzywdzonych - dla sprawców), a także obowiązki o charakterze probacyjnym, które mają szczególne znaczenie dla wzmocnienia procesu resocjalizacyjnego i wychowawczego, obejmując m.in. możliwość zobowiązania skazanego przez sąd do podjęcia terapii uzależnień czy oddziaływań korekcyjno-edukacyjnych. Ponadto mają zróżnicowany charakter i zawarte są w katalogu otwartym, co daje sądowi w zasadzie nieograniczoną 
możliwość kreowania wobec skazanego obowiązków takiego postępowania, które zapobiegnie przestępczości powrotnej.

Opinię o skuteczności oddziaływań na sprawcę przestępstwa, w tym systemu readaptacji społecznej, możemy kształtować m.in. przez pryzmat powrotności do przestępstwa, tj. liczby osób, które dopuściły się przestępstwa po zapadnięciu pierwszego prawomocnego wyroku sądu, która w ostatnich latach kształtowała się następująco (zob. wykres 4).

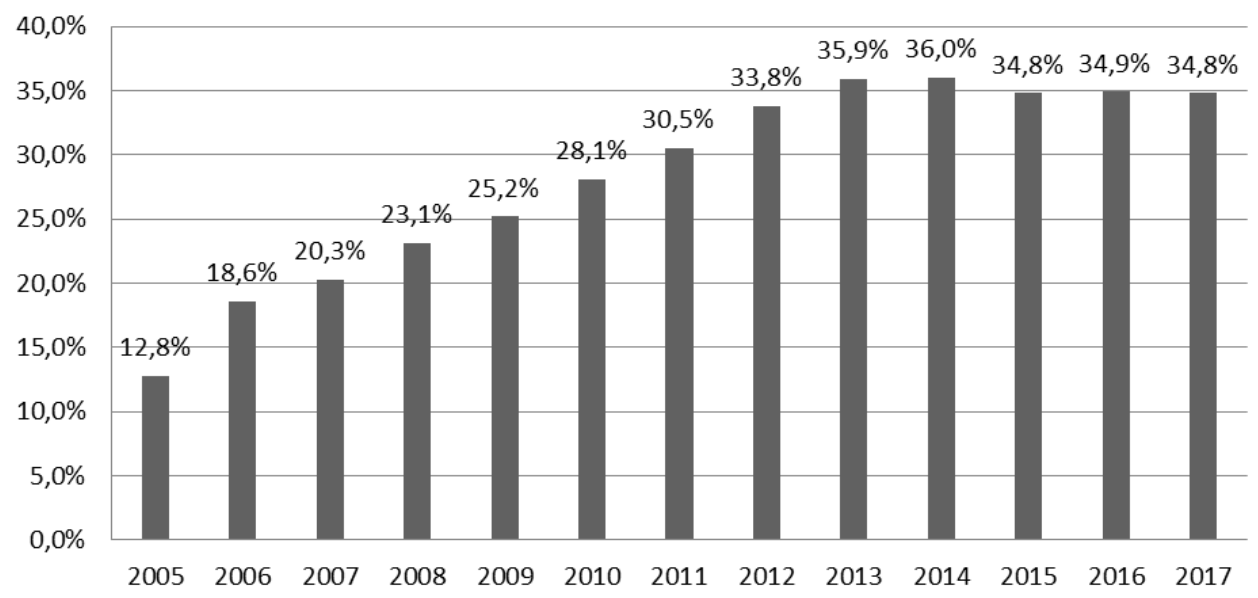

Wykres 4. Odsetek skazanych uprzednio karanych w ogólnej liczbie skazanych w latach 2005-2017 w sądach pierwszej instancji. Opracowanie własne.

Źródło: https://www.sw.gov.pl/strona/statystyka-roczna [dostęp: 2018.07.25].

Do 2014 r. mieliśmy do czynienia ze stale wzrastającym udziałem osób już karanych wśród ogółu osób skazanych. Można ostrożnie wnioskować, że tendencja ta została trwale przełamana w roku 2015, oraz nadmienić, że pojęcie osób powracających do przestępstwa nie jest tożsame z pojęciem recydywy w rozumieniu formalnym (art. $64 \S 1$ i 2 k.k.). Tych bowiem wśród ogółu skazanych odnotowujemy znacząco niższy odsetek, tj. ok. 5,6\% (2017 r.).

Użytecznym narzędziem Ministerstwa Sprawiedliwości jest pozyskiwanie danych o ponownych skazaniach w kolejnych okresach pięcioletnich po prawomocnym wyroku skazującym, w tym w rozbiciu na poszczególne rodzaje kar. Dane za skazania referencyjne w latach 2009-2012 oraz powrotności w kolejnych okresach pięcioletnich są następujące (tabela 1). 
Tabela 1. Powrotność do przestępstwa osób, które po prawomocnym wyroku sądu zostały ponownie prawomocnie skazane w okresie 5 lat, w ujęciu procentowym. Opracowanie własne. Źródło: https://isws.ms.gov.pl/pl/baza-statystyczna/ [dostęp: 2018.06.12]

\begin{tabular}{|l|c|c|c|c|c|}
\hline $\begin{array}{c}\text { Rok } \\
\text { popełnienia } \\
\text { pierwszego } \\
\text { przestępstwa }\end{array}$ & $\begin{array}{c}\text { Całkowita } \\
\text { powrotność } \\
\text { do przestępstwa } \\
\text { w okresie 5 lat }\end{array}$ & $\begin{array}{c}\text { Kara } \\
\text { Bezwzględna } \\
\text { kara } \\
\text { pozbawienia } \\
\text { wolności } \\
\text { wolności } \\
\text { z warunkowym } \\
\text { zawieszeniem } \\
\text { jej wykonania } \\
\text { z dozorem } \\
\text { kuratora } \\
\text { sądowego }\end{array}$ & $\begin{array}{c}\text { Kara } \\
\text { ograniczenia } \\
\text { wolności }\end{array}$ & $\begin{array}{c}\text { Kara grzywny } \\
\text { samoistnej }\end{array}$ \\
\hline 2009 & $25,4 \%$ & $36,2 \%$ & $31,7 \%$ & $35,0 \%$ & $22,6 \%$ \\
\hline 2010 & $25,8 \%$ & $35,4 \%$ & $33,4 \%$ & $34,5 \%$ & $21,9 \%$ \\
\hline 2011 & $25,5 \%$ & $33,7 \%$ & $34,9 \%$ & $32,2 \%$ & $20,4 \%$ \\
\hline 2012 & $24,2 \%$ & $35,4 \%$ & $34,0 \%$ & $29,5 \%$ & $17,3 \%$ \\
\hline
\end{tabular}

Ciekawym materiałem poglądowym, zmuszającym badaczy do podniesienia wiedzy o przyczynach zróżnicowania poziomu przestępczości powrotnej, biorąc pod uwagę charakterystykę regionów, są dane oparte na właściwości miejscowej sądów okręgowych (wykres 5).

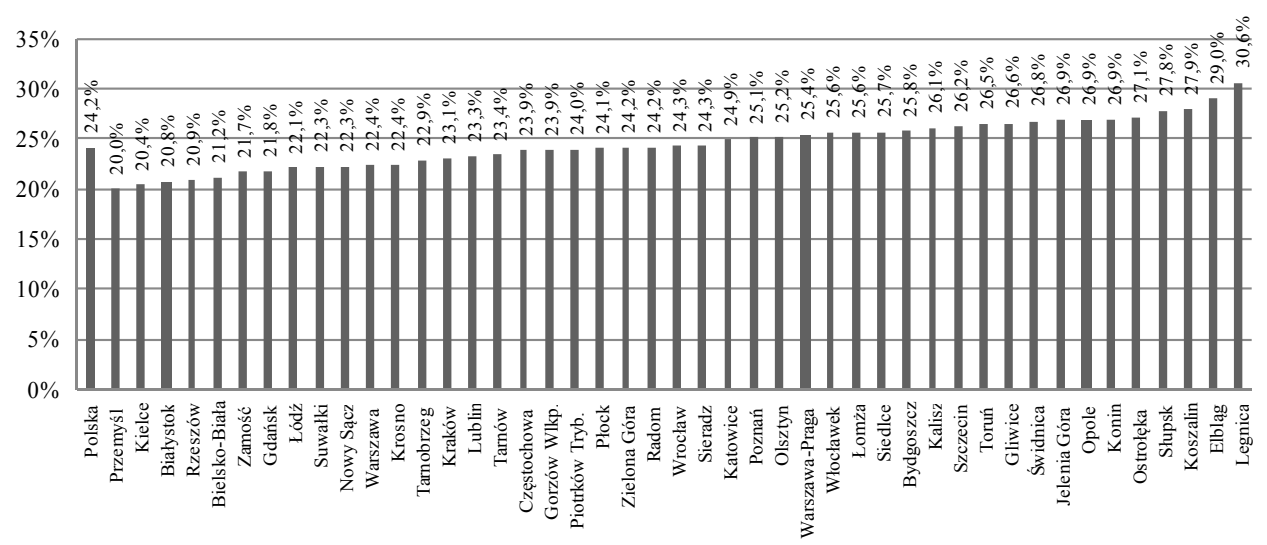

Wykres 5. Udział procentowy skazanych prawomocnym wyrokiem w 2012 roku, którzy ponownie popełnili przestępstwo w okresie kolejnych 5 lat w poszczególnych okręgach sądowych. Opracowanie własne.

Źródło: https://isws.ms.gov.pl/pl/baza-statystyczna/ [dostęp: 2018.06.12].

Jeśli skuteczność kary mierzyć wyłącznie powrotnością do przestępstwa, okazuje się, że jest ona istotnie zróżnicowana i wynosi od $20 \%$ do $30,6 \%$ w zależności od właściwości sądu okręgowego. 
W projektowaniu programu oddziaływania na sprawcę przestępstwa jedną z kluczowych okoliczności jest określenie czasu, w którym oddziaływania mogą być skuteczne. Biorąc pod uwagę, że ponad połowa sprawców przestępstw $(53,5 \%)$ powracających do przestępstwa jest ponownie prawomocnie skazana w pierwszym roku po pierwszym prawomocnym skazaniu, nabieramy przekonania, że służby korekcyjne, podejmując współpracę ze skazanym, mają na podjęcie skutecznej interwencji od kilku do kilkunastu tygodni. W tym czasie celność diagnozy resocjalizacyjnej, sporządzonej we współpracy ze skazanym, powinna prowadzić do prawidłowego programu oddziaływania (uwzględniającego standardy ewaluacji), zawierającego w szczególności program pracy resocjalizacyjnej w oparciu o metody i techniki należące do oddziaływań wychowawczych, resocjalizacyjnych, profilaktycznych oraz do sfery działań readaptacyjnych. Każdy z elementów programu winien być wyodrębniony i określony w czasie oraz wskazywać częstotliwość i formę kontaktu ze skazanym. Oddziaływania, o których mowa, nie mogą mieć charakteru doraźnego i przypadkowego.
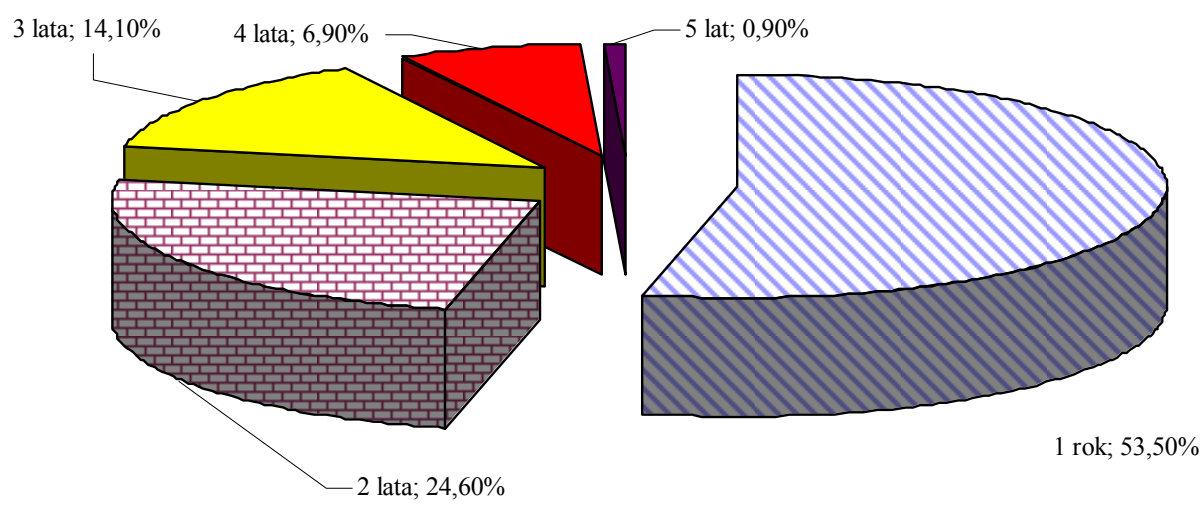

Wykres 6. Procentowy udział skazanych, którzy powrócili do przestępstwa w okresie 5 lat od prawomocnego skazania w 2011 roku,

w ogólnej liczbie powtórnie skazanych w tym okresie. Opracowanie własne.

Źródło: https://isws.ms.gov.pl/pl/baza-statystyczna/ [dostęp: 2018.06.12].

W kolejnych latach ryzyko powrotności do przestępstwa maleje skokowo o około $50 \%$. W drugim roku po prawomocnym skazaniu ponownie skazanych prawomocnie było około $26 \%$, w trzecim już tylko $15 \%$, gdy w czwartym zaledwie około $7 \%$. W piątym roku badania ponownie prawomocnie skazanych było niewiele ponad $1 \%$ skazanych. Oznacza to, że intensywne prowadzenie działań, które mają doprowadzić do zmiany postaw w procesie resocjalizacji, 
może być w zasadzie niecelowe już w trzecim roku po prawomocnym skazaniu. Trzeci i ewentualnie kolejne lata powinny skupiać się już wyłącznie na utrzymaniu uzyskanych efektów z pierwszego roku oddziaływań oraz ich społecznej kontroli, w trakcie której możliwe są działania wzmacniające i redukujące ewentualne napięcia i niepowodzenia skazanego.

Kolejną wskazówką do zmiany myślenia o tradycyjnym procesie readaptacji społecznej skazanych jest wysoki poziom nasycenia polskich więzień osobami, które już wcześniej odbywały karę pozbawienia wolności. Tę sytuację obrazuje wykres 7 .

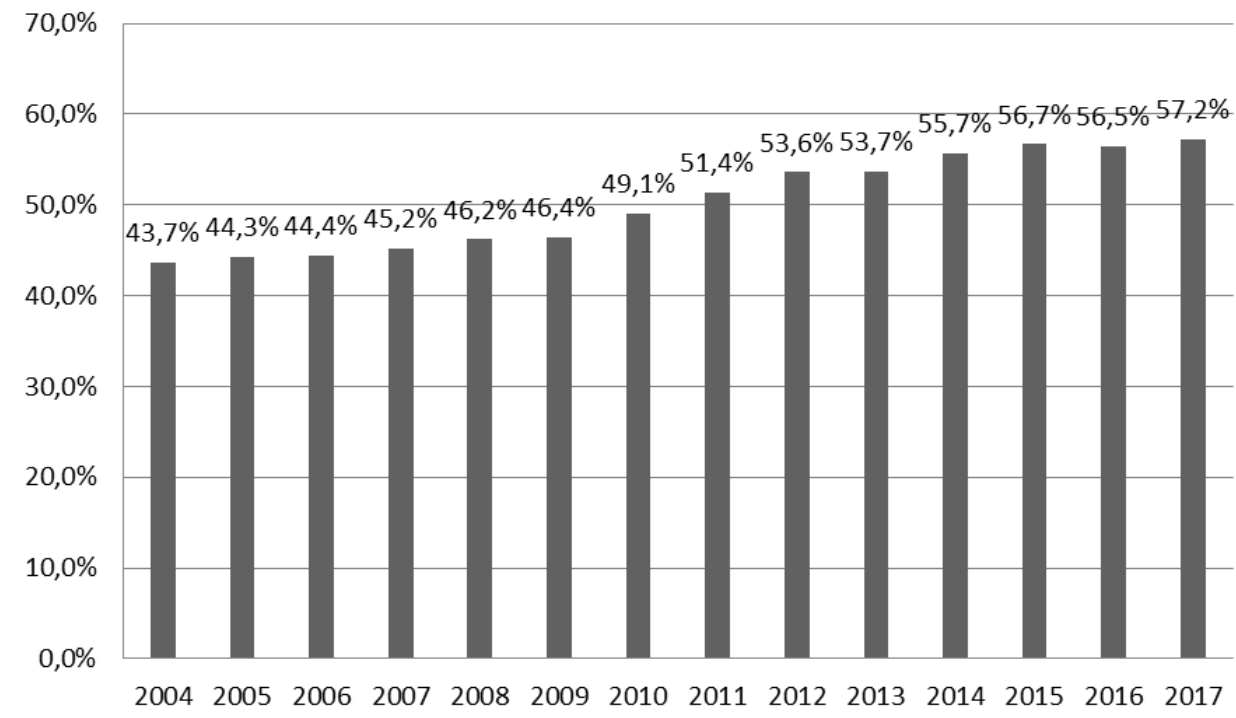

Wykres 7. Procentowy udział skazanych ponownie odbywających karę pozbawienia wolności (art. 64 § 1 i 2 k.k.) w ogólnej liczbie skazanych. Opracowanie własne.

Źródło: https://www.sw.gov.pl/strona/statystyka-roczna [dostęp: 2018.07.24].

Należy zwrócić uwagę na podobieństwo zjawiska powrotności do przestępstwa po prawomocnym skazaniu oraz po odbyciu kary pozbawienia wolności. W obu przypadkach powrotność ta jest najwyższa w pierwszym roku, przy czym w przypadku opuszczających jednostkę penitencjarną oscyluje wokół $18 \%$.

\section{JAK UCZYNIĆ SKUTECZNYM SYSTEM READAPTACJI SPOŁECZNEJ?}

W celu ułatwienia społecznej readaptacji, a w szczególności przeciwdziałania powrotowi do przestępstwa, udziela się skazanym oraz ich rodzinom 
niezbędnej pomocy, zwłaszcza materialnej, medycznej, w znalezieniu pracy i zakwaterowaniu, a także porad prawnych. Tej pomocy udzielają właściwe organy administracji rządowej i samorządu terytorialnego oraz kuratorzy sądowi, a także organizacje pozarządowe, w tym w szczególności stowarzyszenia, fundacje, Kościoły i związki wyznaniowe.

Z punktu widzenia Kodeksu karnego wykonawczego koordynatorem procesu readaptacji społecznej skazanego, przebywającego w środowisku otwartym, jest kurator sądowy. Społeczna readaptacja skazanych jemu powierzona (art. 173 $\S 1$ k.k.w.) ma kapitalne znaczenie dla osiągnięcia dwóch podstawowych celów, tj. urzeczywistnienia utylitarnego celu wykonania kary, jakim jest zapobieżenie powrotności do przestępstwa, a także inkluzji społecznej skazanego opartej na jego samoświadomości.

Bez wątpienia instytucja kurateli sądowej daje możliwość zindywidualizowania oddziaływań wobec skazanego. Aby jednak osiągnąć cel, o którym mowa, musi nastąpić ewolucja w działalności tej służby, prowadząca do pogłębienia profesjonalizacji w wykonywaniu zadań, które związane są z udzieleniem wsparcia w wychodzeniu przez skazanego z sytuacji kryzysowych. Przy czym nie jest konieczne, aby kurator sądowy realizował zadania należące do pracy socjalnej. Jego działania muszą jednak być oparte na wiedzy o instytucjach, które ją realizują. Profesjonalizacja w tym wymiarze będzie zatem oparta między innymi na właściwej diagnozie oraz jej ewaluacji i opartym na niej realnym programie readaptacyjnym, w którego kształtowaniu, w szczególności w zakresie określenia problemów, potrzeb, a następnie wskazania kroków zaradczych, pierwszoplanową rolę powinien odgrywać sam probant. Celem postępowania nie jest bowiem potęgowanie ,przyzwyczajenia” instytucjonalnego, postawy roszczeniowej czy też pogłębianie procesów stygmatyzujących skazanego. Jest nim dążenie do stopniowego uwolnienia skazanego od piętna „przestępcy” na rzecz jednostki rozwijającej się w poczuciu własnej wartości i godności, w pełni autonomicznej, kształtującej swoją przestrzeń życiową wewnątrz systemu społecznego, który go akceptuje.

Zrozumienie roli kuratora sądowego jako koordynatora procesu readaptacyjnego sprowadza się zatem do powiązania jej z podmiotem postępowania wykonawczego, nie zaś rolą zawiadowcy działalności instytucji pomocowych, które na różnych jego etapach podejmują działania. Wsparcie skazanego, które w ramach wykonania kary wolnościowej może dotyczyć wielu aspektów jego życia, począwszy od rekonstrukcji więzi rodzinnych poprzez potrzeby edukacyjne, terapeutyczne, socjalne czy bytowe aż do zdrowotnych i integracyjnych, powinno być realizowane aktywnie przez kuratora sądowego. Takie wykonywanie zadań jest możliwe do zrealizowania, przy czym wymaga wiedzy, 
kreatywności, zaangażowania i elastyczności (Chwaszcz, Niewiadomska, Fel, Wiechetek, Palacz-Chrisidis, 2015).

Wyłącznie podejście systemowe do kreowania i organizowania readaptacji społecznej ma szansę na jej urzeczywistnienie. W tym celu niezbędne jest dostrzeżenie jego wszystkich uczestników, określenie istniejących między nimi powiązań, a następnie opisanie ich działań w konkretnej sekwencji dla realizacji konkretnego celu, jakim jest zapobieżenie powrotności do przestępstwa osób uprzednio karanych oraz skuteczne odbudowanie ich więzi ze społeczeństwem.

Zadania z zakresu readaptacji społecznej skazanych w Polsce wykonuje wiele podmiotów i instytucji, bez wyraźnego wskazania lidera całego procesu. Instytucje z reguły zamknięte w swoich strukturach wewnętrznych, pomimo formalnych możliwości, nie potrafią skutecznie współdziałać na zewnątrz poprzez swoich funkcjonariuszy lub przedstawicieli. Ich współpraca powinna polegać na bezpośredniej relacji osób, nie na wyłącznie formalnym kontakcie międzyinstytucjonalnym. Taka działalność może bowiem utrudniać dostrzeżenie podmiotowości osób wymagających interwencji i pomocy w zakresie włączenia społecznego, tym samym realnego humanitarnego wymiaru wykonywania kary, na rzecz administracyjnego załatwienia sprawy. W funkcjonującym modelu readaptacji społecznej skazanych obserwujemy następujące organy i podmioty, które nadają ton rozwojowi systemu:

- Minister Sprawiedliwości, do którego należy określenie prawnych ram funkcjonowania systemu, a także zapewnienie możliwości współpracy międzyresortowej podległym sobie służbom.

- Rada Główna do Spraw Społecznej Readaptacji i Pomocy Skazanym, powoływana przez Prezesa Rady Ministrów w celu koordynowania współdziałania organów państwowych i przedstawicieli społeczeństwa w zapobieganiu przestępczości i wykonywaniu orzeczeń oraz w celu świadczenia pomocy w readaptacji społecznej, a także wykonywania kontroli społecznej i dokonywania oceny polityki penitencjarnej (szerzej o zadaniach Rady Głównej zob. Stasiorowski, 2013).

- Terenowe rady do spraw społecznej readaptacji i pomocy skazanym, które mogą być powoływane przez wojewodów; ich zadania są tożsame z zadaniami Rady Głównej i dostosowane do potrzeb regionu. 
Tabela 2. Podstawowi uczestnicy

oraz wybrane instrumenty readaptacji społecznej w Polsce.

Opracowanie własne.

\begin{tabular}{|c|c|c|c|c|c|c|}
\hline Policja & Prokuratura & $\begin{array}{c}\text { Sądy } \\
\text { powszechne }\end{array}$ & $\begin{array}{c}\text { Służba } \\
\text { Więzienna }\end{array}$ & $\begin{array}{c}\text { Pomoc } \\
\text { społeczna }\end{array}$ & $\begin{array}{l}\text { Instytucje } \\
\text { rynku pracy }\end{array}$ & \begin{tabular}{|c} 
Przedstawi- \\
ciele \\
społeczeń- \\
stwa \\
\end{tabular} \\
\hline $\begin{array}{l}\text { programy } \\
\text { prewencyjne }\end{array}$ & prokuratorzy & sędziowie & $\begin{array}{l}\text { zakłady } \\
\text { karne } \\
\text { i areszty } \\
\text { śledcze }\end{array}$ & $\begin{array}{l}\text { regionalne } \\
\text { ośrodki } \\
\text { polityki } \\
\text { społecznej }\end{array}$ & $\begin{array}{l}\text { publiczne } \\
\text { służby za- } \\
\text { trudnienia }\end{array}$ & $\begin{array}{l}\text { stowarzysze- } \\
\text { nia }\end{array}$ \\
\hline \multirow[t]{7}{*}{$\begin{array}{l}\text { funkcjona- } \\
\text { riusze policji }\end{array}$} & & $\begin{array}{l}\text { kuratorska } \\
\text { służba } \\
\text { sądowa }\end{array}$ & $\begin{array}{l}\text { przywięzien- } \\
\text { ne zakłady } \\
\text { pracy }\end{array}$ & \begin{tabular}{|l} 
ośrodki \\
pomocy \\
rodzinie
\end{tabular} & $\begin{array}{l}\text { Ochotnicze } \\
\text { Hufce Pracy }\end{array}$ & fundacje \\
\hline & & & szkoły & $\begin{array}{l}\text { domy } \\
\text { pomocy } \\
\text { społecznej }\end{array}$ & $\begin{array}{l}\text { agencje } \\
\text { zatrudnienia }\end{array}$ & $\begin{array}{l}\text { Kościoły } \\
\text { i inne związ- } \\
\text { ki wyzna- } \\
\text { niowe }\end{array}$ \\
\hline & & & $\begin{array}{l}\text { służba zdro- } \\
\text { wia }\end{array}$ & $\begin{array}{l}\text { placówki } \\
\text { specjali- } \\
\text { stycznego } \\
\text { poradnictwa, } \\
\text { w tym ro- } \\
\text { dzinnego }\end{array}$ & $\begin{array}{l}\text { instytucje } \\
\text { szkoleniowe }\end{array}$ & $\begin{array}{l}\text { osoby godne } \\
\text { zaufania }\end{array}$ \\
\hline & & & wychowawcy & $\begin{array}{l}\text { ośrodki } \\
\text { wsparcia }\end{array}$ & $\begin{array}{l}\text { instytucje } \\
\text { dialogu } \\
\text { społecznego }\end{array}$ & \\
\hline & & & & $\begin{array}{l}\text { ośrodki } \\
\text { interwencji } \\
\text { kryzysowej }\end{array}$ & $\begin{array}{l}\text { instytucje } \\
\text { partnerstwa } \\
\text { lokalnego }\end{array}$ & \\
\hline & & & & $\begin{array}{l}\text { pracownicy } \\
\text { socjalni }\end{array}$ & $\begin{array}{l}\text { Centrum } \\
\text { informacyj- } \\
\text { no-konsulta- } \\
\text { cyjne służb } \\
\text { zatrudnienia } \\
\text { „Zielona } \\
\text { linia” }\end{array}$ & \\
\hline & & $\begin{array}{l}\text { Fundusz } \\
\text { Sprawiedli- } \\
\text { wości }\end{array}$ & $\begin{array}{l}\text { Fundusz } \\
\text { Sprawiedli- } \\
\text { wości }\end{array}$ & & & $\begin{array}{l}\text { Fundusz } \\
\text { Sprawiedli- } \\
\text { wości }\end{array}$ \\
\hline
\end{tabular}




\subsection{PRZYPISANIE KURATOROWI SĄDOWEMU ROLI KOORDYNATORA PROCESU READAPTACJI SPOŁECZNEJ SKAZANYCH}

Okres do 6 miesięcy przed przewidywanym warunkowym zwolnieniem lub przed wykonaniem kary stanowi, w miarę potrzeby, czas niezbędny na przygotowanie skazanego do życia po zwolnieniu z zakładu karnego lub aresztu śledczego, zwłaszcza dla nawiązania kontaktu z kuratorem sądowym lub organizacją pozarządową. Okres ten ustala, za zgodą skazanego, komisja penitencjarna lub może wyznaczyć sąd penitencjarny w postanowieniu o udzieleniu lub odmowie warunkowego zwolnienia, jeżeli uzna to za niezbędne (art. 164 $\S 1$ i 2 k.k.w.), przy czym w praktyce dominująca większość wniosków jest wynikiem działalności komisji penitencjarnych.

Biorąc pod uwagę wysoki odsetek osób powtórnie odbywających karę pozbawienia wolności wśród ogółu więźniów (wykres 7), a także najwyższy odsetek osób powracających do przestępstwa po uprzednim orzeczeniu kary bezwzględnego pozbawienia wolności (tabela 1), nie ulega wątpliwości, że pierwszym etapem zmian w zakresie poprawy funkcjonowania systemu readaptacji społecznej skazanych, w celu obniżenia przestępczości powrotnej, powinien zostać objęty proces warunkowego przedterminowego zwolnienia skazanego z odbycia reszty kary pozbawienia wolności i przygotowania go do życia na wolności w ramach instytucji opisanej w art. 164 k.k.w. Dotyczy to m.in. możliwości powoływania przez dyrektorów zakładów karnych tzw. komisji (zespołów) ds. readaptacji społecznej skazanych na terenie jednostek penitencjarnych oraz poszerzania składów komisji penitencjarnych.

Podstawowym założeniem systemu jest oparcie działalności jego uczestników na wzajemnej wiedzy o sobie. Współdziałanie między poszczególnymi podmiotami powinno odbywać na zasadach bezpośredniej współpracy osób, a nie wyłącznie formalnej wymianie korespondencji między instytucjami, poprzez spójny i jednolity program oddziaływań resocjalizacyjnych i readaptacyjnych, ustalony już w trakcie pobytu skazanego w jednostce penitencjarnej.

W związku z brakiem możliwości realnego korzystania z dobrodziejstwa art. $165 \S 1$ k.k.w. (zasada, w myśl której skazany powinien - w miarę możliwości - odbywać karę w zakładzie karnym położonym najbliżej przyszłego miejsca stałego pobytu) funkcjonowanie zespołu nie powinno być utożsamiane wyłącznie z jego instytucjonalnym wymiarem, ale również skutecznym działaniem w ramach zintegrowanego systemu teleinformatycznego, wspomagającego proces readaptacji społecznej skazanego. Funkcjonalne połączenie pozornie odrębnie funkcjonujących elementów systemu readaptacji społecznej 
skazanych (realizowane w zróżnicowanych instytucjach i podmiotach) staje się oczywiste przy wykorzystaniu podejścia hybrydalnego, przy czym przez hybrydyzację należy rozumieć sposoby oddzielenia form od istniejących praktyk i rekombinowania nowych form w nowych praktykach (Stochmal, Maciejewski, 2018). Odrębność działalności instytucji i podmiotów nie wyklucza bowiem działania na rzecz systemu. Przeciwnie, odrębność i wzajemne wspomaganie gwarantuje dynamiczny i nieustający ich rozwój przy zastosowaniu narzędzi ewaluacyjnych.

Spotkania członków zespołu, o którym mowa, byłyby okresowe i miałyby strategiczny charakter. Zespół może wykorzystywać już dzisiaj dostępne środki stosowane w pracach komisji penitencjarnych, o których mowa w art. 75 $\S 3$ k.k.w., na którego podstawie, w zależności od potrzeb zakładu karnego, jego dyrektor może zarządzić udział poszczególnych członków komisji penitencjarnej w jej posiedzeniu przy użyciu urządzeń technicznych umożliwiających przeprowadzenie tej czynności na odległość, z jednoczesnym bezpośrednim przekazem obrazu i dźwięku. W codziennym funkcjonowaniu system teleinformatyczny powinien stać się platformą komunikacji i wymiany danych między podmiotami biorącymi udział w readaptacji społecznej skazanych, tj. Służby Więziennej, kuratorskiej służby sądowej, pomocy społecznej, instytucji rynku pracy oraz organizacji pozarządowych. Dostęp do systemu powinny mieć z zewnątrz także osoby uprawnione do korzystania z konkretnych świadczeń, tj. skazani oraz ich najbliżsi.

Zintegrowany system wsparcia readaptacji społecznej jest uzasadniony także z punktu widzenia ekonomicznego, znacząco ograniczając czas pracy funkcjonariuszy i podmiotów, jak i skracając uzyskanie informacji i działania po stronie skazanego i jego najbliższych, którzy korzystaliby z niego, np. poprzez prostą aplikację telefoniczną.

Wśród zalet proponowanego rozwiązania można wymienić w szczególności:

- możliwość przeprowadzenia kompleksowej, jednorazowej interdyscyplinarnej diagnozy opartej na zasadniczych potrzebach, problemach oraz potencjale skazanego;

- wzmożenie aktywności podmiotu postępowania wykonawczego oraz partnerów wspierających proces readaptacji społecznej;

- opracowanie przy aktywnym udziale skazanego jednolitego programu readaptacyjnego; koordynatorem programu, w zależności od etapu wykonania kary, jest: w trakcie odbywanej kary pozbawienia wolności - wychowawca w zakładzie karnym, po uzyskaniu warunkowego przedterminowego zwolnienia - kurator sądowy, zaś po odbyciu kary - pracownik socjalny (na każdym etapie tę rolę mogłaby pełnić również zaangażowana organizacja pozarządowa); 
- zapobieganie zjawisku bezdomności (w 2017 r. około 3,2 tys. osób opuściło zakład karny, nie mając stałego miejsca zamieszkania na wolności); dzięki zintegrowanemu systemowi informatycznemu powstanie możliwość zarezerwowania miejsca zamieszkania dla skazanych opuszczających jednostki penitencjarne w dowolnym hostelu, schronisku, noclegowni, domu dla bezdomnych czy domu pomocy społecznej, podmiocie leczniczym lub innym podmiocie, w którym będzie kontynuował, np. terapię, na terenie kraju; niewykluczone jest podejmowanie działań na rzecz utrzymania lokali mieszkalnych, będących miejscem zamieszkania skazanego przed osadzeniem w jednostce penitencjarnej, w szczególności pozostających w dyspozycji gmin lokali komunalnych (socjalnych) oraz interwencyjnych, umożliwiając im ponowne w nich zamieszkanie po odbyciu kary;

- umożliwienie koordynatorowi programu prawidłowego, selektywnego wykorzystania środków Funduszu Sprawiedliwości w części postpenitencjarnej oraz świadczeń pomocy społecznej;

- możliwość określenia wniosków i zobowiązań skazanego do właściwego postępowania po opuszczeniu jednostki penitencjarnej, które powinny znaleźć odzwierciedlenie m.in. w postanowieniu o warunkowym przedterminowym zwolnieniu z odbycia reszty kary pozbawienia wolności poprzez określenie odpowiednich zakazów, nakazów i obowiązków probacyjnych;

- możliwość określenia celowości orzeczenia przez sąd dozoru kuratora sądowego nad warunkowo zwolnionym bądź organizacji pozarządowej;

- możliwość przejęcia programu po opuszczeniu jednostki penitencjarnej, odpowiednio przez kuratora sądowego (w przypadku warunkowego zwolnienia skazanego) albo pracownika socjalnego (koniec kary) lub organizację pozarządową, która może kontynuować oddziaływania rozpoczęte jeszcze w trakcie odbywania przez skazanego kary pozbawienia wolności.

$\mathrm{Z}$ punktu widzenia formalnego, a także posiadanych kompetencji nie ulega wątpliwości, że jedynym współcześnie organem, który może prowadzić skuteczny ponaddyscyplinarny proces readaptacji społecznej skazanego opuszczającego jednostkę penitencjarną, jest zawodowy kurator sądowy. Przy czym jego „gospodarzem” staje się z chwilą opuszczenia przez skazanego jednostki penitencjarnej. Przykładowy krąg podmiotów, z którymi kurator zawodowy winien współpracować w ramach systemu, dokonując selektywnego doboru podmiotów uzależnionego od potrzeb konkretnego przypadku, przedstawia wykres 8 . Należy przy tym podkreślić, że dobór partnerów nie powinien być utożsamiany z podległością i zależnością służbową. Partnerstwo oznacza w tym przypadku współdziałanie oparte na wzajemnej wiedzy o sobie, zaufaniu oraz określeniu wspólnych celów dla dobra klienta. 


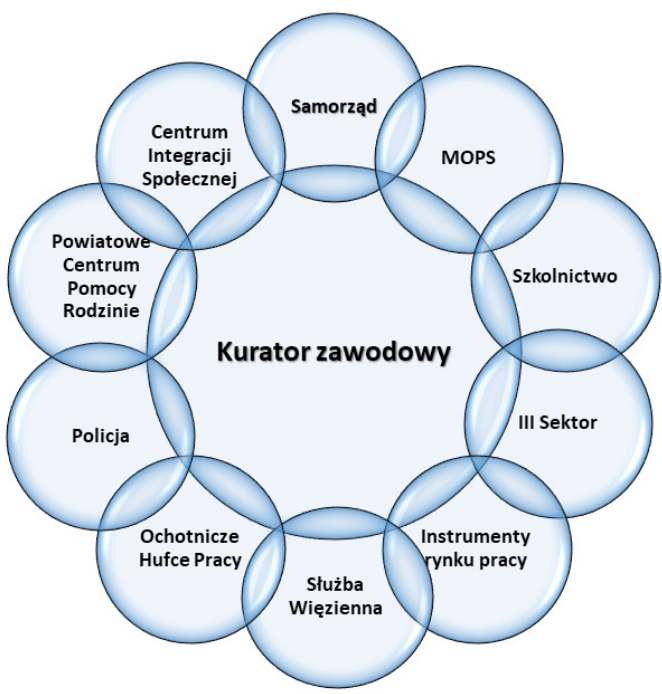

Wykres 8. Kurator w centrum systemu readaptacji społecznej skazanych (oprac. własne).

W trakcie realizacji programu wolnościowego z udziałem zawodowego kuratora sądowego, należy do niego:

1) nawiązanie osobistego kontaktu ze skazanym;

2) przeprowadzenie analizy dostępnej dokumentacji dotyczącej skazanego, rozpoznanie jego sytuacji rodzinnej oraz środowiskowej i na podstawie zebranego materiału opracowania programu wolnościowego dla skazanego;

3) przygotowanie środowiska rodzinnego i społecznego do powrotu skazanego;

4) współorganizowanie pomocy postpenitencjarnej przez rozpoznanie potrzeb skazanego i jego rodziny oraz kształtowanie umiejętności samodzielnego rozwiązywania trudności życiowych, współdziałając ze skazanym i administracją zakładów karnych, a ponadto organami administracji rządowej i samorządu terytorialnego oraz podmiotami, o których mowa w art. $38 \S 1$ k.k.w.;

5) współdziałanie ze stowarzyszeniami, fundacjami, organizacjami, instytucjami i innymi podmiotami, których celem działania jest pomoc w społecznej readaptacji skazanych;

6) współpraca $z$ komisją penitencjarną.

Co istotne, proponowana zmiana jakościowa nie wymaga zmian legislacyjnych. Prawo przewiduje możliwość specjalizowania kuratorów w zakresie prowadzenia przygotowania do wolności, o którym mowa w art. 164 k.k.w., bowiem kierownik zespołu właściwego ze względu na miejsce położenia zakładu karnego może wyznaczyć kuratora zawodowego do spraw związanych z opracowywaniem programów wolnościowych dla skazanych objętych okresem 
przygotowania do życia po zwolnieniu z zakładu karnego i do stałych kontaktów z administracją zakładu karnego, uwzględniając jego wykształcenie, umiejętności i przeszkolenie. Umożliwia to profesjonalizację wykonywanych zadań, a także stałą współpracę z administracją jednostek penitencjarnych i podmiotami współdziałającymi w ramach zespołu. W praktyce jednak dominujący podział zadań oparty na terytorialności funkcjonowania kuratorów sądowych skutecznie powstrzymuje ich rozwój.

W związku ze zdiagnozowanymi problemami, należy przedstawić propozycję rozszerzenia składu komisji penitencjarnej, która ma przemożny wpływ zarówno na ilość prowadzonych programów, jak i ich rodzaj, a także szereg kompetencji autonomicznych wobec skazanego. Dlatego też obok dyrektora zakładu karnego albo osoby przez niego wyznaczonej oraz funkcjonariuszy SW w składzie komisji powinni zasiadać kurator zawodowy oraz - w razie potrzeby lub możliwości - przedstawiciele innych podmiotów, o których mowa w art. 38 k.k.w., a także pomocy społecznej.

Prezentowany poniżej, uproszczony schemat postępowania w ramach przygotowania skazanego do życia po opuszczeniu jednostki penitencjarnej (wykres 9) stanowi hybrydę obecnie funkcjonujących i planowanych lub rozwijanych działalności i zadań instytucji oraz podmiotów, które mogą mieć decydujący wpływ na skuteczne przywrócenie skazanego społeczeństwu poprzez utrzymanie ich odrębności, przy jednoczesnym nadaniu im nowych funkcjonalności i form współpracy. Przy tak szeroko rozbudowanym aparacie wykonania kary, pomocy socjalnej i rynku pracy za niezbędne należy uznać zainwestowanie w kapitał ludzki, którego działania powinny być nastawione na skuteczność, oparte na wiedzy, profesjonalizmie i zaangażowaniu.

Biorąc pod uwagę możliwości rozwojowe współcześnie działających instytucji, służb i podmiotów, trzeba podkreślić, że powoływanie nowych instytucji wsparcia, pozornie opartych na społeczeństwie, np. ,asystentów readaptacyjnych”, jest chybione i będzie prowadziło wyłącznie do rozrostu aparatu urzędniczego, powodując chaos kompetencyjny. Już dzisiaj obserwujemy przerost rozbudowanych systemów wykonania kary, wsparcia socjalnego i rynku pracy, które w różnej mierze dublują swoje zadania. Ich działalność wymaga jedynie skutecznego, systemowego wykorzystania oraz realnego partnerstwa z podmiotami będącymi emanacją samoświadomości społecznej, eksponowanej głównie przez działalność organizacji non profit. Wskazane działania, oparte na podejściu systemowym, mogą mieć znaczący wpływ na obniżenie powrotności do przestępstwa oraz do zakładów karnych osób uprzednio karanych. Poprzez rzetelną ewaluację działalności poszczególnych elementów systemu, tj. funkcjonowania konkretnych instytucji, służb i innych podmiotów współuczestniczących, daje możliwość realnego modelowania opisanych procesów. 


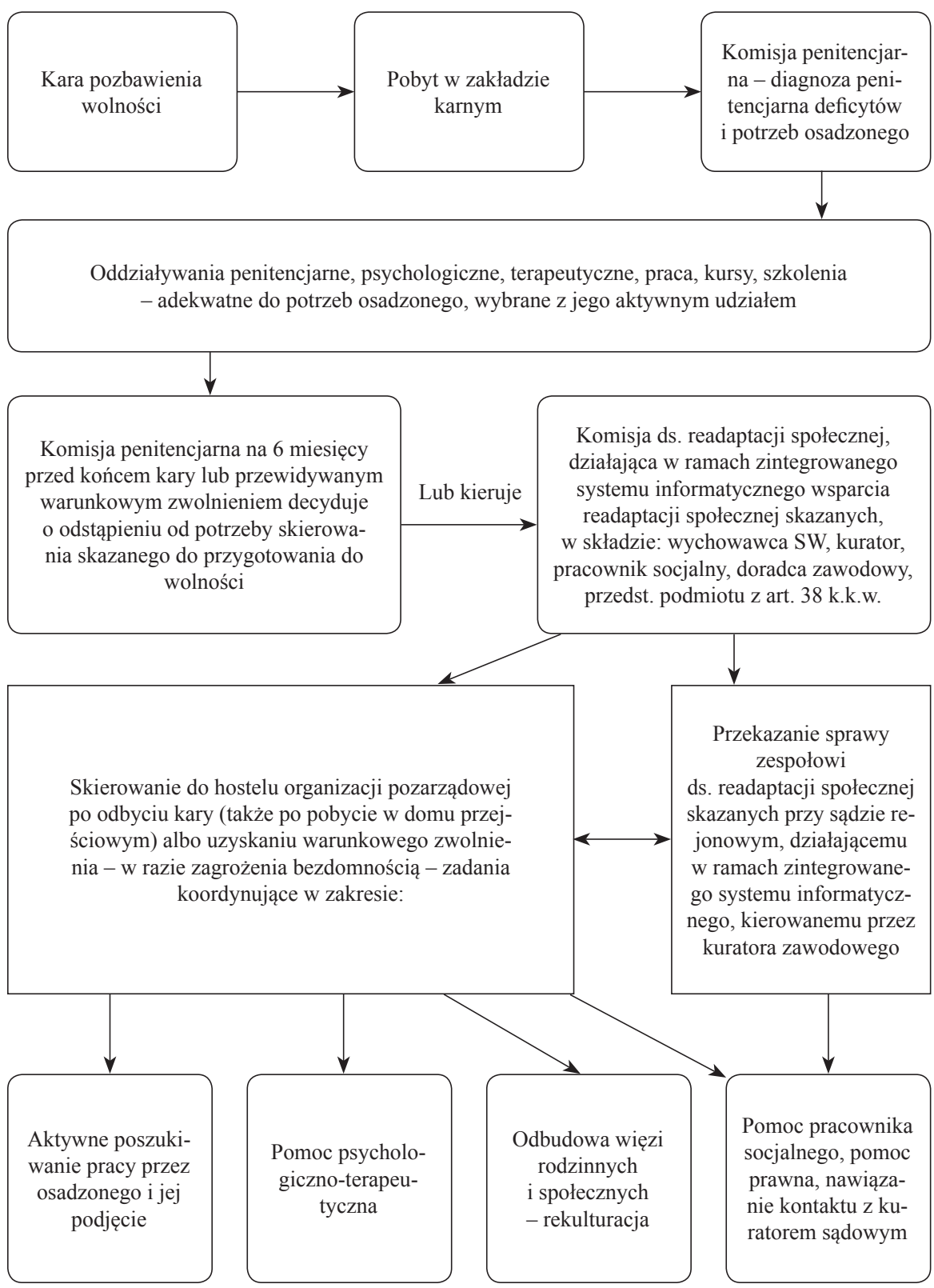

Wykres 9. Schemat przygotowania do wolności oraz przykładowe zadania podstawowych uczestników (oprac. własne).

Źródło: Reforma systemu readaptacji społecznej skazanych w Polsce. Warszawa 2016. Opracowana na podstawie doświadczeń Rady Głównej ds. Społecznej Readaptacji i Pomocy Skazanym oraz rad terenowych ds. społecznej readaptacji i pomocy skazanym, w szczególności województwa warmińsko-mazurskiego i OISW w Olsztynie. 


\section{BIBLIOGRAFIA}

Chwaszcz, J., Niewiadomska, I., Fel, S., Wiechetek, M., Palacz-Chrisidis, A. (2015). Innowacyjne narzędzia do diagnozy potencjału readaptacyjnego osób zagrożonych wykluczeniem społecznym i zawodowym. Warszawa: Wydawnictwo Naukowe PWN.

HoŁYst, B. (2016). Kryminologia (wyd. 11). Warszawa: Wydawnictwo Naukowe PWN.

Jaroch, W. (2012). Polityka karna - strategia punitywna czy liberalna. Studia Prawnoustrojowe, 15/12, 49-61.

Krukowski, A. (1982). Problemy zapobiegania przestępczości. Warszawa: PWN.

PierzchaŁa, K. (2015). The Process of Social Reintegration of Convicts on the Background of World Penitentiary System. The Analytical and Synthetic Outline of the Issue [Proces readaptacji społecznej skazanych na tle światowego systemu penitencjarnego. Zarys analityczno-syntetyczny zagadnienia]. Polskie Towarzystwo Nauk Politycznych i Polska Akademia Nauk. Polish Political Science. Yearbook, 44, 154-170.

PierzchaŁa, K. (2016). Destygmatyzacja przestępców w świetle Magisterium Kościoła oraz pogladów na resocjalizację. Kraków: Oficyna Wydawnicza „Impuls”.

Stasiorowski, S. (2013). Uczestnictwo społeczeństwa w wykonywaniu orzeczeń - cele i zadania Rady Głównej do Spraw Społecznej Readaptacji i Pomocy Skazanym. Probacja, 2, 143-156.

Stochmal, M., Maciejewski, J. (2018). Hybrydyzacja obszarów badawczych środowiska (nie) bezpieczeństwa nie tylko w dyscyplinie socjologii. Historia i Polityka, 23 (30), 87-101.

\section{SPRAWOZDANIA}

Sprawozdanie MS-S6 w sprawie osób osądzonych w pierwszej instancji według właściwości rzeczowej. Ministerstwo Sprawiedliwości.

\section{ŹRÓDŁA PRAWA}

Ustawa z dnia 6 czerwca 1997 r. Kodeks karny, Dz. U. z 2017 r., poz. 2204, t.j. ze zm.

Ustawa z dnia 6 czerwca 1997 r. Kodeks karny wykonawczy, Dz. U. z 2018 r., poz. 652, t.j.

Rozporządzenie Ministra Sprawiedliwości z dnia 9 czerwca 2003 roku w sprawie standardów obciążenia pracą kuratora zawodowego, Dz. U. 2003, nr 116, poz. 1100.

Rozporządzenie Ministra Sprawiedliwości w sprawie sposobu i trybu wykonywania czynności przez kuratorów sądowych w sprawach karnych wykonawczych, Dz. U. z 2016 r., poz. 969.

\section{NETOGRAFIA}

International Centre form Prison Studies, http://www.prisonstudies.org/country/poland [dostęp: 18.06.2018].

http://www.prisonstudies.org/country/poland [dostęp: 18.06.2018].

Baza statystyczna Ministerstwa Sprawiedliwości, https://isws.ms.gov.pl/pl/baza-statystyczna/, [dostęp: 12.06.2018].

Dane statystyczne dotyczące wykonania kary pozbawienia wolności oraz funkcjonowania Służby Więziennej pochodzą ze strony, https://www.sw.gov.pl/dzial/statystyka, [dostęp: 24.07 2018]. 


\title{
PODSTAWOWE CZYNNIKI WPŁYWAJĄCE NA FUNKCJONOWANIE SYSTEMU READAPTACJI SPOŁECZNEJ SKAZANYCH - DIAGNOZA I ROZWÓJ
}

\section{Streszczenie}

\begin{abstract}
Zmieniający się obraz polityki karnej Państwa i wiodąca w niej rola kar alternatywnych wobec kary pozbawienia wolności, tj. kary grzywny oraz ograniczenia wolności, przy jednoczesnym ograniczeniu funkcji wychowawczo-resocjalizacyjnej kuratora sądowego, prowadzą niepostrzeżenie do ewolucji jego zadań. Jednocześnie rosną oczekiwania w zakresie podniesienia skuteczności działań mających na celu pomoc skazanemu opuszczającemu jednostkę penitencjarną w społecznej readaptacji, która zazwyczaj postrzegana jest przez pryzmat świadczeń i usług o charakterze wspierającym, materialnym lub administracyjnym. Dostrzegając te zjawiska, autor artykułu prezentuje systemowe podejście do readaptacji społecznej skazanych oparte na nowym, hybrydalnym modelu przygotowania skazanego do życia na wolności. System opierający się na wzajemnej wiedzy o sobie jego uczestników jest nieskomplikowany, zrozumiały i winien być powszechny. Centralną w nim rolę upatruje w instytucji kuratora sądowego, którego zadania nie zostały precyzyjnie określone przepisami prawa. Jednocześnie wskazano na możliwości, jakie daje obserwacja funkcjonującego systemu pod względem jego skuteczności, która może być wykorzystywana w prognozie powrotności do przestępstwa sprawców objętych jego oddziaływaniami.
\end{abstract}

Słowa kluczowe: readaptacja społeczna; resocjalizacja; kurator sądowy; probacja.

\section{MAIN FACTORS DETERMINING THE FUNCTIONING OF THE SYSTEM OF SOCIAL RE-ADAPTATION OF OFFENDERS - DIAGNOSIS AND DEVELOPMENT}

\begin{abstract}
Summary
The changing picture of the state's criminal policy and the leading role of sanctions alternative to deprivation of liberty, i.e. the sanctions of fine and restriction of liberty, accompanied with limited educational-rehabilitative role of a probation officer, lead imperceptibly to the evolution of his tasks. At the same time, there is a growth in the expectations regarding the improvement of effectiveness of tasks aiming at helping an ex-convict to social rehabilitation that is usually perceived as providing supporting, material or administrative provisions and services. Recognizing these phenomena, the author presents a systemic approach to social re-adaptation of convicts, relying on a new, hybrid model of a preparation of a convict to live without liberty restrictions. The system, based on participants' mutual knowledge about themselves, is not complicated, is comprehensible and should become common. The Author sees the institution of a probation officer, whose tasks have not been precisely legally described, having a central role in the system. At the same time, it has been indicated what possibilities are given by the observation of the functioning system, considering its effectiveness that may be used in the prognosis of re-offending regarding the convicts who will be subject to system's influence.
\end{abstract}

Key words: social re-adaptation; social rehabilitation; probation officer; probation. 